Fairness and Justice: Jurnal Ilmiah Ilmu Hukum

p-ISSN: 1858-0106 e-ISSN: 2502-3926

Volume 17 Nomor 1 Mei 2019, Hlm 1-17

http://jurnal.unmuhjember.ac.id/index.php/FAJ

\title{
Keabsahan Perjanjian Pengikatan Jual Beli Yang Digantungkan Pada Kewajiban Pembayaran Utang
}

\author{
Denise Elysia \\ Magister Kenotariatan Fakultas Hukum Universitas Airlangga \\ Email : elysia.denise@gmail.com
}

\begin{abstract}
The sale and purchase binding agreement is a legal breakthrough that was born out of the needs of the community. Used by the parties as a preliminary agreement because it has not been able to fulfill the conditions to carry out the sale and purchase before the officials of the land deed. However, in practice, binding of sale and purchase agreement is made not because of the sale and purchase transaction but as debt guarantee which the debtor plays as the seller and the creditor as the buyer. So the problem is how the legitimacy of binding agreement of sale and purchase as well as the sale power suspended as debt guarantee? then what is the basis of legal considerations for judges in deciding cases binding sale and purchase agreement that hung as debt guarantee ?. This research is a normative juridical research by using approach of legislation, concept and case. From the result of the research, it is concluded that the deed made by the parties before the notary is valid as an authentic deed which has been in accordance with the legislation, and the sale power is a unity in the sale and purchase agreement, where the seller authorizes the buyer to do duty rather than an authorizer. The sale power made by the parties is also an authentic deed and not an absolute authority prohibited by the Instruction of the Minister of Home Affairs Number 14/ 1982 because it does not contain an element of transfer of rights. Based on several considerations of the judge, it can be deduced that as long as the deed of sale and purchase agreement of sale and sale has been made and executed legally as authentic deed which has perfect evidentiary power, then the deed can not be canceled.
\end{abstract}

Keywords: Binding Sale and Purchase Agreement, Legality, Recognition of Debt.

\begin{abstract}
Abstrak
Perjanjian pengikatan jual beli merupakan sebuah terobosan hukum yang lahir karena kebutuhan masyarakat. Digunakan oleh para pihak sebagai perjanjian pendahuluan karena belum dapat dipenuhinya syaratsyarat untuk melaksanakan jual beli dihadapan pejabat pembuat akta tanah. Namun pada praktiknya perjanjian pengikatan jual beli dibuat bukan karena adanya transaksi jual beli tetapi sebagai jaminan utang yang mana debitur berposisi sebagai penjual dan kreditur sebagai pembeli. Maka yang menjadi permasalahan adalah bagaimana keabsahan
\end{abstract}


Fairness and Justice: Jurnal Ilmiah Ilmu Hukum

p-ISSN: 1858-0106 e-ISSN: 2502-3926

Volume 17 Nomor 1 Mei 2019, Hlm 1-17

http://jurnal.unmuhjember.ac.id/index.php/FAJ

perjanjian pengikatan jual beli serta kuasa jual yang ditangguhkan sebagai jaminan utang ? kemudian apa dasar pertimbangan hukum bagi hakim dalam memutus perkara perjanjian pengikatan jual beli yang digantungkan sebagai jaminan utang ?. Penelitian ini merupakan penelitian yuridis normatif dengan menggunkan pendekatan perundangundangan, konsep dan kasus. Dari hasil penelitian maka diperoleh simpulan adalah bahwa akta yang dibuat para pihak dihadapan notaris tersebut adalah sah merupakan akta otentik yang telah sesuai dengan peraturan perundang-undangan, serta kuasa jual merupakan satu kesatuan dalam akta perjanjian pengikatan jual beli dimana penjual memberikan kuasa kepada pembeli untuk melakukan kewajiban daripada pemberi kuasa. Kuasa jual yang dibuat oleh para pihak juga merupakan akta otentik dan bukan termasuk kuasa mutlak yang dilarang oleh Instruksi Menteri dalam Negeri Nomor 14/ 1982 karena tidak mengandung unsur pemindahan hak. Berdasarkan beberapa pertimbangan hakim dapat ditarik kesimpulan bahwa sepanjang akta perjanjian pengikatan jual beli dan kuasa jual telah dibuat dan dilaksanakan secara sah sebagai akta otentik yang mempunyai kekuatan pembuktian sempurna, maka akta tersebut tidak dapat dibatalkan.

Kata Kunci: Perjanjian Pengikatan Jual Beli, Keabsahan, Pembayaran Utang.

\section{Pendahuluan}

Dalam kehidupan bermasyarakat sering ditemui adanya perbuatan hukum berupa peminjaman uang antara dua orang atau lebih. Perjanjian yang terjalin disebut perjanjian utang piutang, atau pinjam meminjam sebagaimana yang diatur dalam Pasal 1754 BW yaitu "pinjam meminjam adalah suatu perjanjian dengan mana pihak yang satu memberikan kepada pihak yang lain suatu jumlah tertentu barang-barang yang menghabis karena pemakaian, dengan syarat bahwa pihak yang terakhir ini akan mengembalikan sejumlah yang sama dari jenis dan mutu yang sama pula".

Para pihak yang melakukan praktik pinjam meminjam uang, membingkai perbuatan hukumnya dengan membuat suatu perjanjian. Pasal 1867 BW menyebutkan bahwa pembuktian dengan tulisan dapat 
Fairness and Justice: Jurnal Ilmiah Ilmu Hukum

p-ISSN: 1858-0106 e-ISSN: 2502-3926

Volume 17 Nomor 1 Mei 2019, HIm 1-17

http://jurnal.unmuhjember.ac.id/index.php/FAJ

dilakukan dengan tulisan otentik atau dengan tulisan di bawah tangan. Pasal 1870 BW kemudian menegaskan bahwa akta otentik memberikan suatu bukti yang sempurna, terkuat tentang apa yang termuat di dalamnya, sepanjang berhubungan langsung dengan pokok isi akta. Di masyarakat walaupun masih ada yang membuat perjanjian peminjaman uang yang dilakukan selain menggunakan akta otentik yaitu, secara tertulis tetapi di bawah tangan atau secara lisan.

Perjanjian pinjam meminjam yang dilakukan antara debitor dan kreditor dituangkan dalam sebuah perjanjian dalam akta yang dibuat oleh notaris, dan telah memenuhi unsur-unsur dari syarat sahnya suatu perjanjian. Serta memuat nilai utang, jangka waktu, penetapan bunga, dan obyek yang dijadikan jaminan utang. Perjanjian tersebut diharapkan akan membuat para pihak yang terikat dalam perjanjian memenuhi segala kewajibannya dengan baik. Namun di dalam perjanjian pinjam meminjam tersebut terkadang ada salah satu pihak yang tidak memenuhi perjanjian yang telah disepakati. Obyek jaminan merupakan salah satu bentuk pengamanan dalam perjanjian utang piutang. Berdasarkan ketentuan Pasal 1131 BW yang menentukan bahwa, "Segala kebendaan si berutang, baik yang bergerak maupun yang takbergerak, baik yang sudah ada maupun yang akan ada dikemudian hari, menjadi tanggungan untuk segala perikatan perseorangan". Dengan adanya obyek jaminan membuat kreditor mendapat perlindungan hukum agar dapat memperoleh pelunasan utang yang menjadi haknya.

Akan tetapi, pada kenyataannya, ada beberapa pihak yang hadir dihadapan notaris dan meminta dibuatkan akta perjanjian pengikatan jual beli selanjutnya disebut PPJB, beserta akta kuasa untuk menjual. Pemberian PPJB beserta kuasa untuk menjual yang dibuat setelah adanya perjanjian pinjam meminjam, perlu kajian yuridis lebih lanjut. Mengingat konstruksi hukum dalam perjanjian pinjam meminjam ini adalah, apabila 
Fairness and Justice: Jurnal Ilmiah Ilmu Hukum

p-ISSN: 1858-0106 e-ISSN: 2502-3926

Volume 17 Nomor 1 Mei 2019, Hlm 1-17

http://jurnal.unmuhjember.ac.id/index.php/FAJ

debitor wanprestasi, maka kreditor berdasarkan PPJB dan kuasa untuk menjual yang telah diberikan kepadanya (pada saat yang yang bersamaan dengan pembuatan perjanjian pinjam meminjam) akan menjual obyek jaminan tersebut untuk mengambil pelunasan piutangnya.

\section{Metode Penelitian}

Untuk kebenaran atas suatu karya ilmiah maka di dalam penelitian harus menggunakan sebuah metodologi yang tepat, karena hal tersebut merupakan pedoman yang menentukan akan kualitas hasil yang didapatkan atas suatu penelitian. Berdasar atas pendapat di atas, penelitian tentang perlindungan hukum keterwakilan perempuan dalam pemilihan umum legislatif dalam tata hukum di Indonesia merupakan penelitian yuridis normatif. Penelitian yuridis normatif merupakan penelitian kepustakaan yang menggunakan sumber bahan hukum kepustakaan. ${ }^{1}$

\section{Hasil dan Pembahasan}

\subsection{Keabsahan Akta Ppjb Beserta Kuasa Untuk Menjual Atas Jamibab Hak Atas Tanah Yang Digantungkan Sebagai Jaminan Utang}

\subsubsection{Syarat Sahnya PPJB}

Perjanjian akan melindungi proses bisnis para pihak, apabila pertama-tama dan terutama, kontrak tersebut dibuat secara sah karena hal ini menjadi penentu proses hubungan hukum selanjutnya. ${ }^{2}$ Suatu perjanjian dianggap sah, apabila suatu perjanjian telah memenuhi syaratsyarat yang telah ditentukan oleh undang-undang, sehingga keberadaan perjanjian tersebut diakui oleh hukum legally concluded contract. ${ }^{3}$ Perangkat

\footnotetext{
${ }^{1}$ Sidi Alkahfi Setiawan. 2013. Perlindungan Hukum Pekerja Pemegang Saham Di PT Bank Central Asia Tbk. Fakultas Hukum Universitas Jember. Jember. hlm. 18

${ }^{2}$ Agus Yudha Hernoko, Op.Cit., h. 156.

${ }^{3}$ Abdulkadir Muhammad, Hukum Perikatan, Citra Aditya Bakti, Bandung, 1990, h. 88. 
Fairness and Justice: Jurnal Ilmiah Ilmu Hukum

p-ISSN: 1858-0106 e-ISSN: 2502-3926

Volume 17 Nomor 1 Mei 2019, HIm 1-17

http://jurnal.unmuhjember.ac.id/index.php/FAJ

aturan hukum tersebut sebagaimana yang diatur dalam buku III BW yaitu:

a. Syarat sahnya kontrak yang diatur dalam Pasal 1320 BW; dan

b. Syarat sahnya kontrak yang diatur di luar Pasal 1320 BW (vide Pasal 1335, Pasal 1337, Pasal 1339 dan Pasal 1347). ${ }^{4}$

Dalam Pasal 1320 BW terdapat empat syarat yang harus dipenuhi untuk sahnya suatu perjanjian yaitu :

a. Sepakat mereka yang mengikatkan dirinya;

b. Kecakapan untuk membuat perjanjian;

c. Suatu hal tertentu;

d. Suatu sebab yang diperbolehkan.

Keempat syarat tersebut merupakan syarat yang mutlak yang harus dipenuhi ketika membuat suatu perjanjian, karena tanpa syarat-syarat tersebut maka perjanjian dapat dianggap tidak pernah ada. Dalam membuat suatu perjanjian yang dibuat dihadapan pejabat yang berwenang, perjanjian akan dituangkan dalam bentuk akta otentik. PPJB hak atas tanah tersebut telah dibuat memenuhi syarat sahnya perjanjian, sehingga perjanjian tersebut mengikat kedua belah pihak sebagaimana mengikatnya undang-undang sesuai dengan ketentuan Pasal 1338 ayat 1 BW bahwa "Semua perjanjian yang dibuat secara sah berlaku sebagai undang-undang bagi mereka yang membuatnya". Perjanjian yang dibuat oleh pihak-pihak jika telah memenuhi syarat sahnya perjanjian, dibuat dengan suatu sebab yang tidak dilarang oleh undang-undang, ketertiban umum dan kesusilaan, dilaksanakan dengan itikad baik dan juga memperhatikan norma yang ikut mengisi suatu kontrak, maka perjanjian tersebut mengikat kedua belah pihak sebagaimana mengikatnya undangundang.

\footnotetext{
${ }^{4}$ Agus Yudha Hernoko, Op.Cit., h. 157.
} 
Fairness and Justice: Jurnal Ilmiah Ilmu Hukum

p-ISSN: 1858-0106 e-ISSN: 2502-3926

Volume 17 Nomor 1 Mei 2019, HIm 1-17

http://jurnal.unmuhjember.ac.id/index.php/FAJ

\subsubsection{Kedudukan Kuasa Untuk Menjual dalam PPJB}

\subsubsection{Makna Pemberian Kuasa}

Perjanjian Pemberian Kuasa (lastgeving) diatur dalam buku III BW Pasal 1792 BW sampai dengan Pasal 1819 BW, sedangkan kuasa (Volmacht) tidak diatur, baik secara khusus dalam BW maupun dalam perundangundangan lainnya, tetapi diuraikan sebagai salah satu bagian dari pembelian kuasa. $^{5}$ Kuasa merupakan kewenangan mewakili untuk melakukan tindakan hukum sepihak yang memberi wewenang kepada penerima kuasa guna kepentingan pemberi kuasa dalam melakukan suatu tindakan hukum tertentu. Dalam arti bahwa kewajiban untuk melaksanakan prestasi hanya terdapat pada satu pihak saja, yaitu penerima kuasa. ${ }^{6}$ Suatu pemberian kuasa pada umumnya merupakan suatu perjanjian sepihak, dimana kewajiban untuk melaksanakan prestasi hanya terdapat pada satu pihak yaitu pada penerima kuasa.

Penerima kuasa tidak boleh melakukan sesuatu apapun yang melampaui kuasanya sesuai dengan ketentuan pada Pasal 1797 BW. Akibat dari ketentuan ini ialah bahwa apa yang dilakukan oleh seorang penerima kuasa dengan melampaui batas wewenangnya, adalah atas tanggungannya sendiri. Berdasar Pasal 1814 BW, pemberi kuasa dapat menarik kembali kuasanya manakala itu dikehendakinya tetapi hal tersebut dapat menimbulkan kerugian bagi hak-hak penerima kuasa. Pemberian kuasa yang lahir karena perjanjian merupakan bagian yang tidak dapat dipisahkan, tanpa adanya kuasa tersebut maka kepentingan penerima kuasa akan sangat dirugikan. Ketentuan Pasal 1814 BW tidak bersifat memaksa sehingga para pihak bebas untuk menyimpang dari

5 Eka Udiana dalam tesisnya, Eksistensi Kuasa Menjual dalam PPJB, Program Pascasarjana Universitas Airlangga, Surabaya, 2009, h. 17.

${ }^{6}$ Herlien Budiono, "Perwakilan, Kuasa dan Pemberian Kuasa", Majalah Renvoi, Nomor 6.42.IV, 3 November 2006, Hal. 69 
Fairness and Justice: Jurnal Ilmiah Ilmu Hukum

p-ISSN: 1858-0106 e-ISSN: 2502-3926

Volume 17 Nomor 1 Mei 2019, Hlm 1-17

http://jurnal.unmuhjember.ac.id/index.php/FAJ

ketentuan Pasal 1814 BW, karena penyimpangan terhadap ketentuaun tersebut dianggap tidak bertentangan dengan kepentingan umum. ${ }^{7}$

\subsubsection{PPJB Beserta Kuasa untuk Menjual yang Mengandung Unsur Kuasa Mutlak}

Untuk menjamin kepastian hukum bagi pembeli maka diberikan kuasa untuk menjual yang mengandung unsur kuasa mutlak oleh penjual. Sehingga nantinya pembeli dapat bertindak dengan sendirinya. Dengan demikian pembeli dapat melakukan perbuatan hukum berdasarkan kuasa yang telah diberikan oleh penjual. Sehubungan dengan dibuatnya akta PPJB beserta kuasa untuk menjual, maka hak dan kewajiban antara kedua belah pihak, terutama mengenai penggunaan kuasa mutlak harus diperhatikan. Notaris harus memperhatikan syarat formil dan materiil agar akta yang dibuatnya dapat berlaku sebagai bukti otentik.

Terkait dengan penggunaan klausula jual tanah dalam sebuah perjanjian PPJB, seringkali masyarakat menggunakan surat kuasa mutlak, yang mana di dalam BW kuasa mutlak tidak dikenal. Istilah kuasa mutlak dijumpai pertama kali dalam hal hipotek, yaitu dalam Pasal 1178 ayat 2 BW. ${ }^{8}$ Di samping diatur dalam ketentuan tersebut, kuasa mutlak juga diatur dalam PP 24/ 1997 serta Instruksi Menteri dalam Negeri Nomor 14 Tahun 1982 tentang larangan penggunaan kuasa mutlak sebagai pemindahan hak atas tanah selanjutnya disebut Instruksi menteri 14/ 1982. Namun demikian surat kuasa mutlak dalam PP 24/ 1997 Pasal 39 ayat 1 hanya mengatur mengenai larangan PPAT untuk membuat akta berdasarkan surat kuasa mutlak.

Dalam Pasal 39 ayat 1 huruf d disebutkan "Salah satu pihak atau para pihak bertindak atas dasar suatu surat kuasa mutlak yang pada

${ }^{7}$ Eka Udiana, Op.Cit., h. 19.
${ }^{8}$ Eka Udiana, Op.Cit., h. 53.

Pengelola: Program Studi Ilmu Hukum Universitas Muhammadiyah Jember

Penerbit: Universitas Muhammadiyah Jember 
Fairness and Justice: Jurnal Ilmiah Ilmu Hukum

p-ISSN: 1858-0106 e-ISSN: 2502-3926

Volume 17 Nomor 1 Mei 2019, Hlm 1-17

http://jurnal.unmuhjember.ac.id/index.php/FAJ

hakikatnya berisikan perbuatan hukum pemindahan hak". Dalam penjelasannya disebutkan bahwa surat kuasa mutlak adalah peberian kuasa yang tidak dapat ditarik kembali oleh pihak yang memberi kuasa, sehingga pada hakekatnya merupakan perbuatan hukum pemindahan hak. Selain itu dalam Instruksi menteri 14/ 1982 juga secara tegas melarang penggunaan kuasa mutlak yang hakekatnya merupakan pemindahan hak atas tanah. Namun demikian menurut yurisprudensi, kuasa mutlak diperbolehkan dalam hal sebagai berikut: ${ }^{9}$

a. Kuasa memasang hipotek;

b. Dalam akta hipotek, untuk menjual sendiri objek hipotek; dan

c. Dalam akta jual beli tanah kuasa mewakili, yaitu kuasa mutlak untuk mewakili si penjual, kalau ternyata si penjual memperoleh izin pemindahan hak atau ia tidak boleh membeli tanah.

\subsubsection{Surat Kuasa untuk Menjual yang Berisikan Perbuatan Hukum Pemindahan Hak}

Kuasa untuk menjual, masuk kedalam kategori kuasa yang digunakan untuk memindahtangankan benda yang sejatinya hanya dapat dilakukan oleh pemiliknya saja. Maka dari itu, untuk kuasa menjual ini, diperlukan suatu pemberian kuasa dengan kata-kata yang tegas di dalam aktanya berdasarkan Pasal 1796 BW. Kuasa untuk menjual ini, bisa masuk sebagai klausul dalam PPJB, bisa juga berdiri sendiri, berbentuk akta tersendiri. Jadi, ketika tanda tangan, menandatangani dua akta: PPJB dan Akta Kuasa Untuk Menjual.

Pencantuman kuasa mutlak pada kluasula akta kuasa untuk menjual tidak dijumpai aturannya di dalam BW namun diatur dalam Yurisprudensi Mahkamah Agung antara lain pada: Putusan MA tanggal

\footnotetext{
${ }^{9}$ I.G Rai Widjaya, Merancang Suatu Kontrak: Contract Drafting Teori dan Praktek, Megapoin, Jakarta, 2003, h. 95. 
Fairness and Justice: Jurnal Ilmiah Ilmu Hukum

p-ISSN: 1858-0106 e-ISSN: 2502-3926

Volume 17 Nomor 1 Mei 2019, Hlm 1-17

http://jurnal.unmuhjember.ac.id/index.php/FAJ

16 Desember 1967 No. 731 K/Sip/1975; dan Putusan MA tanggal 17 Nopember 1987 No. 3604 K/Pdt/1985. Dalam Putusan MA mengakui keberadaannya kuasa mutlak sebagai suatu kebutuhan hukum. Putusan MA tanggal 16 Desember 1967 No. 731 K/Sip/1975 telah menegaskan bahwa ketentuan Pasal 1813 BW tidak bersifat limitatif dan tidak mengikat oleh karena itu jika sifat perjanjian memang menghendaki, dapat ditentukan pemberian kuasa mutlak tidak dapat dicabut kembali.

Pemberian kuasa mutlak merupakan suatu perikatan yang muncul dari perjanjian, yang diatur Pasal 1338 BW, yang mengakui adanya kebebasan berkontrak, dengan pembatasan bahwa perjanjian tidak boleh bertentangan dengan peraturan perundang-undangan dan harus dilandasi dengan itikad baik. Peraturan perundangan dimaksud adalah Pasal 1320 BW tentang syarat sahnya perjanjian, Pasal 1138 BW tentang pembatasan dari asas kebebasan berkontrak, Pasal 1813 BW tentang berakhirnya pemberian kuasa, Peraturan Pemerintah Nomor 24 Tahun 1997 tentang Pendaftaran Tanah khususnya Pasal 37, Pasal 38, Pasal 39, serta Instruksi menteri 14/ 1982, serta Surat Dirjen Agraria, Menteri Dalam Negeri RI Nomor 594/493/AGR, tanggal 31 Maret 1982.

Dalam masalah ini klausul kuasa mutlak yang terdapat pada akta kuasa untuk menjual adalah bukan yang dimaksud Instruksi Menteri 14/ 1982. Yaitu kuasa mutlak yang pada hakekatnya merupakan pemindahan hak atas tanah adalah kuasa mutlak yang memberikan kewenangan kepada penerima kuasa untuk menguasai dan menggunakan tanahnya serta melakukan segala perbuatan hukum yang menurut hukum hanya dapat dilakukan oleh pemegang haknya, walaupun kuasanya tidak dapat ditarik kembali. Bahwa akta PPJB dan kuasa untuk menjual merupakan tahap awal sebelum dilakukan perbuatan hukum akta jual beli yang dibuat oleh PPAT. Untuk memenuhi ketentuan Pasal 37 PP 24/ 1997 tersebut, maka akta PPJB dan kuasa untuk menjual notaris tersebut harus 
Fairness and Justice: Jurnal Ilmiah Ilmu Hukum

p-ISSN: 1858-0106 e-ISSN: 2502-3926

Volume 17 Nomor 1 Mei 2019, Hlm 1-17

http://jurnal.unmuhjember.ac.id/index.php/FAJ

ditindaklanjuti dengan perbuatan hukum yang dilakukan di hadapan PPAT yang berwenang dengan membuat apa yang disebut dengan akta jual beli, yang fomulirnya telah ditetapkan oleh Menteri. Demikian dengan dibuatnya akta jual beli, maka perbuatan hukum pemindahan hak tersebut dapat didaftarkan di Kantor Pertanahan setempat.

\subsection{Analisis Putusan Mahkamah Agung}

\subsubsection{Putusan Mahkamah Agung Nomor 3037.K/Pdt/2013}

Perkara ini pada Pengadilan Negeri Jakarta Selatan dengan menolak gugatan penggugat, pada peradilan tingkat banding yakni pada Pengadilan Tinggi DKI Jakarta menguatkan putusan Pengadilan Negeri Jakarta Selatan, serta putusan Mahkamah Agung tetap menolak permohonan kasasi yang dilakukan oleh pemohon kasasi, dahulu penggugat/ pembanding. Mahkamah Agung tidak melihat bahwa perjanjian tersebut sebenarnya merupakan perjanjian utang piutang dengan jaminan rumah milik Drs. Setiawan Sumanang, karena telah lahir PPJB, kuasa jual, serta akta pengosongan yang dibuat dan ditanda tangani oleh Drs. Setawan Sumanang sebagai penjual dan tergugat I dan II sebagai pembeli.

Dalam kasus ini peralihan hak telah di daftarkan oleh pembeli yaitu Rossy Fania, dibeli dari pihak yang namanya tertera pada Sertipikat Hak Milik Nomor 351/Bangka yaitu Muhamad Andy Arslan Djunaid dan Kadafi Yahya berdasarkan Akta Jual Beli Nomor 05/2010 tanggal 26 April 2010 yang dibuat oleh PPAT Ida Fidiyantri. Oleh karena itu telah secara sah menjadi pemegang hak atas Sertipikat Hak Milik Atas Tanah Nomor 531/ Bangka yang terletak di Jalan Kemang Raya 41 A Jakarta.

\subsubsection{Putusan Mahkamah Agung Nomor $661 \mathrm{~K} / \mathrm{Pdt} / 2009$}


Fairness and Justice: Jurnal Ilmiah Ilmu Hukum

p-ISSN: 1858-0106 e-ISSN: 2502-3926

Volume 17 Nomor 1 Mei 2019, Hlm 1-17

http://jurnal.unmuhjember.ac.id/index.php/FAJ

Mahkamah Agung menolak gugatan yang diajukan oleh pemohon kasasi dan menyatakan bahwa pembuatan PPJB dan Kuasa Menjual tersebut sudah benar sesuai dengan kesepakatan para Penggugat dan Tergugat I dan sesuai prosedur. PPJB dan kuasa jual yang dibuat sebagai perjanjian pendahuluan, telah diadakan perjanjian lanjutan berupa pembuatan akta jual beli dan telah diajukan permohonan atas balik nama serta telah dikeluarkan sertipikat atas nama tergugat. Oleh sebab itu, adanya perjanjian ikatan jual beli telah cukup membuktikan dan ditindaklanjuti dengan pembuatan akta jual beli adalah sudah tepat dan benar. Akibatnya peralihan hak dari Penggugat ke Tergugat I atas dasar akta PPJB dan ditindaklanjuti dengan akta jual beli adalah sah dan berkekuatan hukum.

Dalam kasus ini peralihan hak telah di daftarkan oleh pembeli yaitu Elya Fatchawari, dan telah diterbitkan sertipikatnya oleh badan pertanahan nasional kota Kediri yaitu pada Sertipikat Hak Milik Nomor 1517/Desa Bandar Kidul, 1264/ Desa Bandar Kidul, dan 478/Desa Tinalan. Berdasarkan Akta Jual Beli Nomor 25 tanggal 27 Februari 2006 yang dibuat oleh PPAT Warsiki Poernomowati. Oleh karena itu telah secara sah menjadi pemegang hak atas Sertipikat Hak Milik Atas Tanah tersebut.

\subsubsection{Putusan Pengadilan Tinggi DKI Jakarta Nomor 130/PDT/2004/PT.DKI}

Perkara ini berawal dari penjual atau debitur yang melayangkan gugatan pada pembeli/ kreditur. Pada pengadilan tigkat satu hakim telah memutus dengan gugatan yang dilayangkan penggugat diterima oleh hakim. kemudian pada peradilan tingkat banding yakni pada Pengadilan Tinggi DKI Jakarta menguatkan putusan Pengadilan Negeri Jakarta Barat. Pada pengadilan tingkat dua ini tergugat terdahulu/ kreditur menjadi 
Fairness and Justice: Jurnal Ilmiah Ilmu Hukum

p-ISSN: 1858-0106 e-ISSN: 2502-3926

Volume 17 Nomor 1 Mei 2019, Hlm 1-17

http://jurnal.unmuhjember.ac.id/index.php/FAJ

penggugat dan penggugat terdahulu/ debitur menjadi tergugat. Namun putusan pengadilan adalah menguatkan putusan pada pengadilan tingkat satu, sehingga gugatan penggugat ditolak. Hakim melihat bahwa belum terjadinya perpindahan hak milik, sehingga akta yang dibuat tidak memiliki kekuatan hukum yang mengikat bagi para pihak.

Kuasa luas yang dibuat oleh notaris Sotemo Ramelan telah sesuai dikarenakan pembuatan surat kuasa luas bukan merupakan perjanjian pokok yang mengandung unsur pemindahan hak tetapi perjanjian tambahan. Dapat diketahui bahwa kuasa luas dibuat secara terpisah dengan akta PPJB namun keduanya merupakan suatu kesatuan yang bulat dan utuh serta tidak dapat dipisahkan. Pemberian kuasa ditujukan untuk memberikan perlindungan bagi pihak penerima kuasa/ pembeli dalam hal ini adalah Drs. Krisna Setya. Kuasa yang dibuat bertujuan agar penerima kuasa dapat melakukan tindakan pemilikan dan tindakan pengurusn tanpa persetujuan dari pihak pemberi kuasa. Hakim memutuskan bahwa PPJB bukan merupakan sebagai bukti terjadinya peralihan hak, dan kuasa luas yang dibuat oleh para pihak melanggar ketentuan instruksi menteri 14/ 1982. Berdasarkan penjelasan diatas dapat disimpulkan bahwa PPJB beserta kuasa luas yang dibuat para pihak tidak melanggar ketentuan dalam instruksi meneteri 14/ 1982 hanya saja kedudukannya menjadi akta dibawah tangan.

\subsubsection{Perlindungan Hukum Bagi Para Pihak}

Dalam akta kuasa jual terdapat pihak pemberi kuasa dan penerima kuasa. Perlindungan hukum bagi pemberi kuasa merupakan hal yang sangat penting mengingat penerima kuasa melakukan suatu perbuatan hukum untuk kepentingan pemberi kuasa. Berdasarkan hasil penelitian dapat disimpulkan bahwa pembuatan akta kuas jual dalam suatu akta otentik dapat memberikan suatu perlindungan hukum bagi para pihak, 
Fairness and Justice: Jurnal Ilmiah Ilmu Hukum

p-ISSN: 1858-0106 e-ISSN: 2502-3926

Volume 17 Nomor 1 Mei 2019, Hlm 1-17

http://jurnal.unmuhjember.ac.id/index.php/FAJ

mengingat dalam hal ini Notaris selaku pejabat umum yang berwenang membuat akta otentik dapat memberikan saran-saran hukum sehingga kuasa menjual yang dibuat dapat memberikan perlindungan hukum yang berimbang bagi para pihak.

Akta kuasa jual yang dibuat oleh notaris dilarang melanggar asas nemo plus iuris ad alium transferre potest quam ipse habet, yang berarti bahwa seseorang tidak dapat mengalihkan hak kepada orang lain lebih daripada hak yang dimiliknya, sehingga pemberi kuasa tidak dapat memberikan kuasa lebih daripada hak atau kewenanangan yang dimiliknya. ${ }^{10}$ Suatu kuasa bukan suatu peralihan hak. Pemberian kuasa atau lastgeving adalah suatu persetujuan, dengan mana seorang memberikan kekuasaan kepada seorang lain, yang menerimanya untuk atas namanya menyelenggarakan suatu urusan. ${ }^{11}$ Pada umumnya suatu pemberian kuasa merupakan perjanjian sepihak dalam arti bahwa kewajiban untuk melaksanakan prestasi hanya terdapat pada satu pihak saja, yaitu pada penerima kuasa. ${ }^{12}$

Perlindungan hukum terhadap pemenuhan hak-hak para pihak apabila salah satu pihak melakukan wanprestasi dalam PPJB sangat tergantung kepada kekuatan dari PPJB yang dibuat, yaitu jika dibuat dengan akta dibawah tangan maka perlindungannya sesuai dengan perlindungan terhadap akta dibawah tangan, sedangkan apabila di buat oleh atau dihadapan notaris maka dengan sendirinya aktanya menjadi akta notaril sehingga kekuatan perlindunganya sesuai dengan perlindungan terhadap akta otentik.

${ }^{10}$ Indradi Prajanto dalam tesisnya, Formulasi Bentuk Komparisi Akta Peralihan Hak Atas Tanah dalam Harta Bersama untuk Menjaga dan Memenuhi Ketentuan Asas Nemo Plus Juris Transfere Potest Quam Ipse Habel, Program Pascasarjana Universitas Atma Jaya, Yogyakarta, 2016, h. 17.

${ }^{11}$ Djaja S. Meliala, Op.Cit., h. 13.

${ }^{12}$ Ibid.

Pengelola: Program Studi Ilmu Hukum Universitas Muhammadiyah Jember

Penerbit: Universitas Muhammadiyah Jember 
Fairness and Justice: Jurnal Ilmiah Ilmu Hukum

p-ISSN: 1858-0106 e-ISSN: 2502-3926

Volume 17 Nomor 1 Mei 2019, Hlm 1-17

http://jurnal.unmuhjember.ac.id/index.php/FAJ

Berdasarkan semua keterangan di atas terlihat bahwa perlindungan hukum yang dapat diberikan terhadap pemenuhan hak semua pihak dalam pengikatan jual beli selain sesuai perlindungan hukum yang diberikan oleh kekuatan akta otentik juga dapat berlandaskan Pasal 1338 BW, serta niat baik dari para pihak untuk memenuhi kesepakatan yang telah dibuat. Ada tiga kondisi seseorang tidak mendapat perlindungan hukum yaitu terlalu baik hati, kurang hati-hati serta tidak pandai. ${ }^{13}$ Dalam hal ini karena posisi debitur lebih lemah maka sebelum melakukan perbuatan hukum agar lebih hati-hati.

\section{Kesimpulan}

Berdasarkan uraian pembahasan yang telah disampaikan di dalam bab sebelumnya pada artikel ini, dapat ditarik beberapa kesimpulan. Beberapa kesimpulan tersebut yakni sebagai berikut:

a. Kekuatan hukum dari PPJB dan kuasa jual yang dibuat oleh para pihak adalah sah karena telah memenuhi syarat sahnya suatu perjanjian menurut Pasal 1320 BW, yang mana mengikat kedua belah pihak sebagaimana mengikatnya undang-undang berdasar Pasal 1338 ayat 1 BW. Selain itu PPJB dan kuasa jual dibuat oleh notaris dan dalam bentuk yang telah ditetapkan oleh undang-undang mempunyai kekuatan pembuktian sempurna, karena merupakan akta notariil yang merupakan akta otentik. Maka akta itu mengikat pihak ketiga, kecuali dapat dibuktikan sebaliknya. Pemberian kuasa yang tidak dapat ditarik kembali dalam akta kuasa jual bukanlah termasuk ke

${ }^{13}$ Didik Endro Purwoleksono, Tiga Kondisi Seseorang Tidak Mendapat Perlindungan Hukum, disampaikan pada mata kuliah Hukum Pidana Jabatan Notaris, 10 Oktober 2017. 
Fairness and Justice: Jurnal Ilmiah Ilmu Hukum

p-ISSN: 1858-0106 e-ISSN: 2502-3926

Volume 17 Nomor 1 Mei 2019, Hlm 1-17

http://jurnal.unmuhjember.ac.id/index.php/FAJ

dalam kuasa mutlak yang dilarang oleh Intruksi Menteri Nomor 14/ 1982 karena tidak mengandung unsur pemindahan hak, sehingga status hukumnya adalah sah

b. Berdasarkan beberapa putusan Mahkamah Agung dan Pengadilan dapat disimpulkan bahwa PPJB serta kuasa jual yang dibuat oleh para pihak adalah sah apabila telah dilakukan sesuai dengan peraturan perundang-undangan yang berlaku. Majelis hakim tidak melihat apakah perjanjian yang dilakukan tersebut memang merupakan hubungan jual beli atau digunakan untuk mempermudah kreditur mengeksekusi apabila debitur wanprestasi. Sepanjang akta telah dibuat secara sah di hadapan notaris maka dengan sendirinya aktanya menjadi akta notaril sehingga kekuatan perlindunganya sesuai dengan perlindungan terhadap akta otentik, maka maksut dan tujuan para pihak tidak termasuk sebagai pertimbanagan hakim dalam memutus perkara. 
Fairness and Justice: Jurnal Ilmiah Ilmu Hukum

p-ISSN: 1858-0106 e-ISSN: 2502-3926

Volume 17 Nomor 1 Mei 2019, Hlm 1-17

http://jurnal.unmuhjember.ac.id/index.php/FAJ

\section{Daftar Pustaka}

\section{$\underline{\text { Buku }}$}

Hatta, Sri Gambir Melati. (2000). Beli Sewa Sebagai Perjanjian Tak Bernama: Pandangan Masyarakat dan Sikap Mahkamah Agung Indonesia, Bandung: Alumni

Hernoko, Agus Yudha. (2000). Hukum Perjanjian Asas Proporsionalitas dalam Kontrak Komersial, Jakarta: Kencana Prenada Media Group

Meliala, Djaja. (1982). Pemberian Kuasa Menurut Kitab Undang-Undang Hukum Perdata. Bandung: Tarsito

Muhammad, Abdulkadir. (1990). Hukum Perikatan. Bandung: Citra Aditya Bakti

P.N.K, Simanjuntak. (1999). Pokok-Pokok Hukum Perdata Indonesia. Jakarta: Djambatan

Pradjodikoro, Wirjono. (2000). Asas-asas Hukum Perjanjian. Bandung: Sumur (2001). Pokok-pokok Hukum Perdata, Jakarta, Intermasa, 2001.

Widjaya, I.G Rai, Merancang Suatu Kontrak: Contract Drafting Teori dan Praktek. Jakarta: Megapoin

\section{Tesis atau Disertasi}

Sidi Alkahfi Setiawan. (2013). Perlindungan Hukum Pekerja Pemegang Saham Di PT Bank Central Asia Tbk. Fakultas Hukum Universitas Jember

Eka Udiana dalam tesisnya. (2009). Eksistensi Kuasa Menjual dalam PPJB. Program Pascasarjana Universitas Airlangga

Indradi Prajanto dalam tesisnya. (2016). Formulasi Bentuk Komparisi Akta Peralihan Hak Atas Tanah dalam Harta Bersama untuk Menjaga dan Memenuhi Ketentuan Asas Nemo Plus Juris Transfere Potest Quam Ipse Habel, Program Pascasarjana Universitas Atma Jaya 
Fairness and Justice: Jurnal Ilmiah Ilmu Hukum

p-ISSN: 1858-0106 e-ISSN: 2502-3926

Volume 17 Nomor 1 Mei 2019, Hlm 1-17

http://jurnal.unmuhjember.ac.id/index.php/FAJ

Muhamad Satria dalam disertasinya. (2014). Prinsip IktikadBaik dalam PPJB Hak Atas Tanah, Program Pascasarjana Universitas Airlangga.

Didik Endro Purwoleksono. (2017). Tiga Kondisi Seseorang Tidak Mendapat Perlindungan Hukum, disampaikan pada mata kuliah Hukum Pidana Jabatan Notaris, 10 Oktober 2017.

\section{Daftar Putusan}

Putusan Pengadilan Tinggi Jakarta Nomor 130/PDT/2004/PT.DKI tanggal 10 Juni 2004.

Putusan Mahakamah Agung Republik Indonesia Nomor : 661.K/Pdt/2009 tanggal 28 Februari 2011.

Putusan Mahakamah Agung Republik Indonesia Nomor : 3037.K/Pdt/2013 tanggal 25 Maret 2014. 